\title{
Conflito Político-Religioso e Embate Discursivo entre Eunômio de Cízico e Basílio de Cesaréia: utilização do manual de Aristóteles ${ }^{1}$
}

Politico-religious Conflict and Discursive Clash between Eunomius of Cizic and Basil of Caesarea: application of the manual of Aristotle

Helena Amália PAPA

Resumo: Os bispos cristãos Eunômio de Cízico (335-394 d.C.) e Basílio de Cesaréia (329/331-379 d.C.) representavam os ideais político-religiosos de dois grupos: cristãos arianos e cristãos nicenos, respectivamente. As contendas que permearam essa temática buscaram a legitimidade de uma ortodoxia religiosa baseado em suas interpretações sobre a natureza do Verbo, a segunda pessoa da Trindade. Dentre os inúmeros grupos religiosos que discutiram o tema objetivamos, neste artigo, compreender as circunstâncias do desenvolvimento da controvérsia ariana a partir do conflito entre o ariano Eunômio de Cízico e o niceno Basílio de Cesaréia. Nossa proposta vai além dos aspectos puramente religiosos e teológicos, pois depositamos na análise retórica uma metodologia para encontrar elementos do ideal e da propaganda político-religiosos desses dois bispos cristãos. Para atingir tal fim, pretendemos analisar e comparar seus testemunhos Apologia e Contra Eunômio, respectivamente, empregando o manual de Aristóteles Arte Retórica.

Palavras-chave: Antiguidade Tardia; Conflito político-religioso; Arianismo; Eunômio de Cízico; Basílio de Cesaréia.

\begin{abstract}
The Christian bishops Eunomius of Cyzic (335-394 AD) and Basil of Caesarea (329/331379 AD) represented the politico-religious ideals of two christian groups: Arian Christians and Christians Nicene, respectively. The contentions that permeated this theme sought the legitimacy of the Orthodox religion based on its interpretations of the nature of Logos, the second person of the Trinity. Within the enumerable religious groups that have discussed the theme, we have aimed in this article to understand the circumstances of the development of the Aryan controversy starting from the conflict between the Aryan, Eunomius of Cizic, and the Nicene, Basil of Caesarea (329/331-379 AD). Our purpose has gone beyond the purely religious and theological aspects, as we have set down in the rhetorical analysis, a methodology to find elements of the ideal and the politico-religious propaganda of these two Christian bishops. To achieve this end, we intend to analyze and compare their testimonies Apology e Against Eunomius, respectively, using the manual Aristotle's Rhetorical Art.
\end{abstract}

Keywords: Late Antiquity; Politico-religious Conflict; Arianism; Eunomius of Cizic; Basil of Caesarea.

\section{Introdução}

A análise do desenvolvimento do cristianismo e, até mesmo de sua doutrina, está intimamente ligada com a compreensão do contexto histórico no qual está inserido. Uma reflexão acerca dos acontecimentos do período faz-se necessária para o historiador que almeja conhecer os meandros de desenvolvimento da afirmação e/ou reafirmação do discurso cristão em quaisquer sociedades, independentemente do recorte temporal desejado.

\footnotetext{
- Mestre em História - Doutoranda - Programa de Pós-graduação em História - Faculdade de História, Direito e Serviço Social de Franca - UNESP - Univ. Estadual Paulista, Campus de Franca - Av. Eufrásia Monteiro Petráglia, 900, CEP: 14409-160, Franca, São Paulo, Brasil. Bolsista CAPES. E-mail: helenapapa@gmail.com
} 
Propomo-nos estudar uma temática que faz parte do processo de legitimação e formação doutrinária cristãs e temos consciência da influência que carregamos do nosso presente já que, no momento atual, o cristianismo é considerado uma crença estabelecida no nosso mundo ocidental. No que pese sua grande inserção em nossa sociedade, o cristianismo continua sendo um assunto polêmico. Hoje visualizamos uma multiplicidade de interpretações cristãs e de formas com as quais elas se relacionam com a sociedade, a partir de seus adeptos que estão inseridos no contexto político, econômico, social e cultural de nossa sociedade. Consideramos impossível pensar em uma História da Igreja ou em uma História do desenvolvimento do discurso cristão sem levar em consideração o momento atual dessa polêmica questão.

Para tentar entender melhor essa polêmica, ou seja, a divindade de Jesus pregada pelas religiões cristãs da atualidade é que voltamos nosso olhar ao passado, especificamente para o século no qual o cristianismo passou da ilegalidade (313 d.C.) para sua oficialização (381 d.C.). Nosso intento recai sobre a questão do desenvolvimento da doutrina cristã, na qual a questão da divindade do Logos, a segunda pessoa do dogma trinitário, está inserida. Ao buscar o estabelecimento de uma ortodoxia cristã, uma das discussões teológicas que mais se sobressaiu no cenário do século IV d.C. foi a que almejava dar uma uniformidade às interpretações cristológicas, ou seja, aquelas que discutiam a respeito da natureza de Jesus. A fim de compreender as circunstâncias do desenvolvimento da controvérsia ariana destacamos o embate discursivo entre os bispos: o niceno ${ }^{2}$ Basílio de Cesaréia (329/331-379 d.C.) e o ariano ${ }^{3}$ Eunômio de Cízico (335-394 d.C.).

No século IV d.C., período no qual essa contenda está inserida, visualizamos uma crescente e estratégica política-administrativa dos imperadores ao intervirem nos assuntos político-religiosos. Essa relação Igreja/Estado ocorreu de muitas maneiras, dentre as quais destacamos os conflitos político-religiosos ocasionados a partir da associação entre as reuniões eclesiásticas (sínodos e concílios episcopais) e o Poder Imperial.

A produção discursiva dos homens é o reflexo de seus pensamentos e de suas atitudes, perante o contexto histórico-político-cultural, nos quais eles se encontram. Dessa forma, podemos considerar os discursos assaz relevantes, pois denotam pensamentos políticos, culturais e dados administrativos da época do autor, em nosso caso, os bispos Eunômio de Cízico e Basílio de Cesaréia. Depositamos na análise retórica uma metodologia para encontrar elementos do ideal e da propaganda político-religiosos desses cristãos. O embate discursivo representado por seus testemunhos Apologia (datado de 360 d.C.), de Eunômio de Cízico, e Contra Eunômio (datado de 363-365 d.C.), de Basílio de Cesaréia, apresenta aqueles ideais político-religiosos defendidos pelos cristãos arianos e cristãos nicenos, respectivamente. Dessa forma, nosso objetivo, no presente artigo, é interpretar tal embate discursivo por meio da análise e comparação retórica dos 
documentos evidenciando que tais bispos cristãos utilizaram técnicas retóricas contidas no manual de Aristóteles Arte Retórica.

A contenda entre os bispos nicenos e arianos perpassou o ambiente de disputa dos concílios e pretendeu abranger o maior número de adeptos a cada uma das partes. Sendo assim, os textos escritos possuíam um papel de destaque na propaganda do ideal político-religioso de cada grupo. Esses discursos tinham o intuito de propagar a doutrina de seu autor, bem como, possuíam o importante papel de se sobrepor aos discursos de seus oponentes que circulavam nesse cenário. O que percebemos é um embate discursivo realizado por meio da retórica aplicada a defender determinado pensamento e ideal cristãos. Em nosso caso, o embate discursivo entre o Apologia e o Contra Eunômio utilizou-se da estratégia retórica para tentar persuadir seu público a adotar determinada fé como verdade.

O embate discursivo retórico está diretamente ligado aos embates conciliares, já que muitos dos discursos foram proclamados, divulgados, apoiados, recriminados, julgados e/ou reprovados nos sínodos e concílios. A contenda ariana pode ser visualizada a partir do embate entre bispos e o poder central e, também, por meio da disputa hierárquica dentro do próprio cristianismo. Portanto, visualizamos essa querela inserida em dois planos: o primeiro pode ser representado pelas relações entre o episcopado e o poder central, no qual percebemos a relação bispo-bispo através das disputas pelo apoio imperial e pelas sedes episcopais; e o segundo plano, mais subjetivo, no qual a contenda está inserida na preocupação da unidade territorial do Império Romano. Esta unidade foi pretendida em meios político-religiosos através de um credo unificado, ou seja, de um cristianismo unificado sob o título de ortodoxo.

Para decodificarmos esse conflito, levando em consideração os dois planos supracitados, pretendemos interpretar esse embate discursivo por meio da comparação retórica, pois acreditamos que a análise retórica pode nos auxiliar a entender os meandros da contenda. Logo, por meio da comparação retórica dos discursos de Eunômio e Basílio, podemos esclarecer como uma contenda hierárquica entre dois bispos estava inserida na disputa entre esses religiosos e o poder central. Vale a pena lembrar que o discurso considerado vencedor, sob a imposição do governo central, foi aquele que obteve apoio do imperador. Ao legitimar determinado discurso político-religioso, o imperador também estava adotando um discurso próprio, centrado em sua proposta político-cultural.

\section{A Retórica no século IV d.C.: considerações sobre a utilização de Aristóteles}

Os embates discursivos nos levam a refletir certas práticas culturais presentes na Antiguidade, como a maneira que os antigos construíram e elaboravam seus textos. A discussão suscitada para compreender os elementos os quais compunham um discurso daquele período é guiada pelo nosso 
presente. Sendo assim, ao interpretarmos um dado histórico, as questões propostas estão intimamente ligadas ao intervalo de tempo que existe entre nós, historiadores, e as práticas culturais daqueles romanos. Quando objetivamos a compreensão do papel da retórica na Antiguidade, também propomos a debater a nossa relação com esse mundo antigo, do qual somos herdeiros (CHIAPETTA, 2001, p.39-40).

Anne Gangloff (2002, p.25), em um estudo sobre a relação entre os mitos e a retórica no período Imperial Romano, afirma que a retórica era a base da paidéia greco-latina. No que diz respeito ao século IV d.C., sabemos que nessa época ainda perpetuava o valor à instrução, o que pode ser exemplificado pelo fato da profissão de retor ser oficialmente reconhecida. Lembramos que Basílio de Cesaréia, após seus estudos nas Escolas de Cesaréia, Constantinopla e Atenas, adotou inicialmente a profíssão de retor, antes de seguir a carreira monástica. Os professores de retórica se consideravam primordiais na preparação dos que ocupariam altos cargos administrativos, religiosos e os que tinham chance de chegar ao cargo de imperador (CARVALHO, 2002, p.27). Miguel Spinelli nos corrobora:

As Escolas almejavam, acima de tudo, e sob o título de filósofos, fazer dos acadêmicos bons retores, transformá-los em exímios dialéticos. [...]. A Retórica, em sentido amplo, era tida como a ciência da palavra ou do discurso (gramaticalmente ordenada com sentido e elegância); a Dialética, por sua vez, era a ciência que se ocupava com os mecanismos da argumentação (SPINELLI, 2002, p.294).

Os vários saberes ensinados nas escolas, tais como: a Ciência das Coisas do Alto (atualmente entendida como Meteorologia), Astrologia, Geometria, a Ciência dos Números (entendida como Aritmética) estavam condicionados ao aprendizado da retórica que obtinha a dialética como uma atividade metodológica, conforme trecho supracitado. Sendo as escolas do Império Romano frequentadas por cristãos e não-cristãos, é importante ressaltar que a paidéia dos homens do século IV d.C. era a mesma. O que percebemos é que essa paidéia foi aplicada de diferentes maneiras, a fim de atender a ideais político-culturais distintos, logo, não concordamos com as seguintes denominações: paidéia cristã, paidéia não-crista, paidéia nicena, paidéia ariana, dentre outras.

Ao tratar especificamente da retórica no Império Romano Tardio, Averil Cameron (1994) utiliza o termo "retórica clássica" para diferenciar daquela utilizada pelo cristianismo que, ainda segunda a autora, auxiliou na afirmação do discurso cristão. Entretanto, Cameron (1994, p.20-21) ressalta que a questão não deve ser vista como "uma simples oposição binária" entre os grupos existentes no século IV d.C., pois as culturas clássica e cristã estavam entrelaçadas, sendo constantemente transformadas e aprimoradas.

Os cristãos acoplaram um ideal político-religioso e utilizaram a retórica clássica como um dos meios para propagar e difundir suas ideias. Em nosso caso, tanto cristãos nicenos quanto cristãos 
arianos, converteram a retórica clássica em uma retórica com propósitos político-religiosos que determinaram sua posição doutrinária em busca de apoio de novos adeptos e do imperador. A questão cristológica obteve fundamental importância na apropriação dessa retórica clássica, na qual a retórica cristã apoiou-se em uma dimensão política para alcançar seus propósitos (CAMERON, 1994, p.169-170, 226). Sobre essa apropriação, Margarida Maria de Carvalho nos indica:

[...] tanto na retórica clássica como na cristã, coube ao orador, aquele que transmitia o discurso, a responsabilidade de defender a si próprio, sua família, sua propriedade e, principalmente, suas idéias políticas: enfim, ser o porta-voz dos interesses do grupo social a que pertencia (CARVALHO, 2002, p.26).

A bibliografia que aborda especificamente a retórica grega tardia ainda é muito escassa quando comparada à época grega clássica e até mesmo, sob o Principado Romano, na qual obteve em Cícero, Quintiliano e Tertuliano seus grandes apogeus. Entretanto, os chamados Estudos Clássicos, muito tem contribuído para o estudo da questão a partir de suas propostas temáticas. Um exemplo disso é a análise de Laurent Pernot (2006), na qual o autor se propõe a estudar as intersecções entre a retórica e a religião na Antiguidade.

Ao tratar da questão, Pernot (2006, p.235) propõe o uso do termo 'retórica-religiosa', ao afirmar que tais formas foram expressões incluídas nos discursos sobre as coisas divinas. Quando essa Arte do Discurso começou a dar embasamento à religião e tradição cristãs, a retórica passou a ser o grande alicerce das discussões das doutrinas teológicas e, consequentemente, ao nosso ver, da contenda aqui analisada. Sendo assim, Pernot (2006, p.240) defende que os discursos cristãos, bem como suas homilias e sermões, são expressões religiosas dignas de uma análise retórica.

Os discursos religiosos podem ser analisados por meio de termos retóricos, pois a retórica mostra essa dimensão divina proposta pelos religiosos do período. $\mathrm{O}$ diálogo entre duas realidades, religião e retórica, podem ser explicados e explanados por afinidades que existem entre a persuasão e a crença na fé. Essas afinidades podem ser visualizadas até mesmo no exemplo dos discursos antireligiosos que utilizavam a retórica para refutar um adversário religioso (PERNOT, 2006, p.253).

Nossa proposta vai além, pois depositamos na análise retórica, uma metodologia para encontrar elementos do ideal e da propaganda político-religiosos, de Eunômio e Basílio. Acreditamos que ao selecionar palavras ou adotar determinada postura verbal ${ }^{4}$, esses religiosos assumiam um posicionamento no qual estavam englobados os seus pensamentos políticos. Sendo assim, seus discursos, além de buscarem apoio e adeptos, pretendiam igualmente tornar público o seu pensamento político e, “dessa forma, alcançar o entendimento do maior número de pessoas possíveis; sua arte de persuadir o ouvinte ou o leitor seria fundamental para a realização de sua meta política-cultural” (CARVALHO, 2002, p.180). Cameron (1994, p.39) já indicou essa problemática 
ao propor observar alguns fatores que parecem característicos ao discurso cristão e explorá-los em relação ao contexto de desenvolvimento do Império. Apoiamo-nos nessa argumentação ao afirmar que Eunômio e Basílio sabiam que estavam fazendo um discurso político e não só religioso, pois não queriam somente propor e/ou defender uma doutrina.

A recepção do discurso pelo leitor é mais um dos elementos contidos na prática retórica: esse é mais um dos códigos que devemos ter em mente ao propor uma interpretação retórica do texto, já que a retórica cristã também se preocupou com tal fato.

Manuel Alexandre Júnior (2003, p.99), ao propor um estudo acerca da hermenêutica retórica, defende que, para melhor análise de um texto, é necessário adotar uma metodologia capaz de envolver três aspectos de forma semelhante: valorização do autor, do texto e do leitor. Sobre o assunto, nos elucida que:

a proposta de uma hermenêutica retórica com estes fundamentos assenta num horizonte integrado de interpretações que, simultaneamente, dão justiça ao autor, estuda a sério o texto e afirma o papel fulcral do leitor (ALEXANDRE JUNIOR, 2003, p.114).

No tocante à preocupação do autor com a recepção do leitor e o papel ativo que este detém sob um discurso, Maria Helena N. Brandão afirma que o locutor, em nosso caso, denominado autor:

[...] instaura um diálogo com o discurso do receptor na medida em que o concebe não como um mero decodificador, mas como um elemento ativo, atribuindo-lhe e emprestando-lhe a imagem de um contra-discurso [...] (BRANDÃO, 2007, p.65).

Dessa forma, Brandão (2007, p.8) nos atenta ao fato de que, durante o processo de interpretação do discurso, o 'interlocutor' cria um discurso próprio, a partir de sua subjetividade e contexto específicos. Não queremos, com isso, hierarquizar o autor, texto ou o leitor no processo de interpretação retórica, sendo assim, entendemos que a análise retórica perpassa sobre esses três aspectos.

O destino final de toda argumentação é persuadir o leitor e convencê-lo de nossas ideias. Portanto, todo discurso procura uma estratégia de convencimento que perpassa a busca de legitimidade apoiada na tradição. Logo, da mesma forma em que Basílio de Cesaréia e Eunômio de Cízico buscaram essa legitimidade em grandes nomes da tradição greco-romana, nós, ao defendermos nossas ideias, também fazemos usos do passado.

Todos nós fazemos uso de nosso passado, já que "a História continua, pois como uma narrativa impregnada de retórica" (FUNARI, 2005, p.66). Ao propor nossas ideias, também selecionamos palavras, autores e fragmentos para expor nosso estudo e argumentar com os leitores. Sobre o assunto, citamos Funari: 
A retórica, na Antigüidade presente, de forma direta, nos discursos dos personagens históricos e na iconografia, aparece, em nossa época, de forma mais mediada. A persuasão dá-se pelo uso seletivo das fontes, pelo arranjo dos argumentos, pela seleção de um repertório de imagens e de elementos da cultura material que se conformam à cadeia explicativa posta em marcha pelo historiador. A forma volta a ser importante, a beleza de uma frase ou de um título de livro adquire importância e retorna-se, de maneira original, a uma história ancorada na forma, volta-se à forma literária, ainda que em um contexto muito diverso daquele antigo (FUNARI, 2005, p.66).

No tocante aos usos do passado, presentes nos discursos de Eunômio e Basílio, Gangloff (2002) afirma que as técnicas retóricas (Technai Rhetorikai) utilizadas no Império Romano estavam presentes em obras de tradição grega que visavam o estudo da prática retórica. Essas obras circulavam na época imperial e "propunham uma teoria, ou um conjunto de conselhos e regras complexas destinadas à prática de elaboração de discursos, a fim de converter ou seduzir os destinatários" (GANGLOFF, 2002, p.38).

Os autores do século IV d.C. elaboraram seus discursos tendo como base escritores do passado, como Hermógenes e Aristóteles ${ }^{5}$. Os escritos desses autores consagrados faziam parte de seus estudos de retórica, atuando como manuais de exercícios escolares sobre técnicas e métodos retóricos (PERNOT, 2006, p.236). Sendo assim, as obras de Aristóteles (CAMERON, 1994, p.144. ENRICO; NORELLI, 2000, p.28. CARVALHO, 2002, p.181. SPINELLI, 2002, p.258. GANGLOFF, 2002, p.38. PERNOT, 2006, p.237) estavam presente nas formas retóricas da expressão religiosa, pois “Aristóteles ocupa um importante lugar na teoria e exercícios de retórica que fizeram parte do pensamento das escolas no mundo Greco-Romano" (PERNOT, 2006, p.237).

Ao utilizarem esses manuais, Eunômio e Basílio pretenderam propor um discurso persuasivo e, por meio da arte da persuasão, pretenderam impor a sua fé através do poder das palavras. Logo, pensamos ser necessário tecer algumas considerações acerca de um dos manuais que foi utilizado na composição do Apologia e do Contra Eunômio, a saber: Arte Retórica de Aristóteles.

A Arte Retórica foi composta para uso interno nas escolas, dada a forma de exposição de seu conteúdo em tópicos e os exemplos de mestre renomados como, por exemplo, Demóstenes. Tal obra é considerada um dos primeiros manuais de retórica, cuja datação é discutida por Jean Voilquin e Jean Capelle, tradutores de nossa edição (199-, p.19-25): acreditam que o tratado foi produzido entre os anos 338 e 336 a.C.

Godofredo Telles Júnior, prefaciador da tradução que estamos utilizando, nos informa que, durante o século IV d.C., os trabalhos lógicos de Aristóteles foram reunidos sob o título Organon (Instrumento), no qual encontravam-se os Tópicos ou teoria da demonstração formulada, a partir de uma argumentação, com opiniões prováveis e que levava a uma conclusão provável. Foi a partir de Tópicos que Aristóteles formulou sua teoria da argumentação dialética denominada Arte Retórica. 
A obra é dividida em 3 livros, nos quais, somente o terceiro foi alvo de contestação quanto sua autoria. Entretanto, foi considerado consenso, ainda utilizando as informações dos tradutores da obra, que a autoria é de Aristóteles e "talvez originalmente constituísse obra distinta, mas, de qualquer maneira, é incontestavelmente autêntica" (Trad. Jean Voilquin; Jean Capelle. ARISTÓTELES, 199-, p.22). Nessa obra, Aristóteles, além de definir o que entende por retórica (ARISTÓTELES, I, 2,1), aconselha o orador-autor do seu compromisso com a verdade (I, 2-6) antes de fazer uso de seus conselhos para obter a persuasão e paixão nos ouvintes (I, 2-5).

A fim de seguir seus conselhos, é necessário que o autor escolha sabiamente o gênero que utilizará, sendo este definido a partir do objetivo almejado: o gênero deliberativo, o gênero demonstrativo e o gênero judiciário (I, 3-1). A próxima etapa é definir os três elementos básicos de uma construção retórica, independente do gênero escolhido:

1) A pessoa que fala - Quem?

2) $\mathrm{O}$ assunto - $\mathrm{O}$ que?

3) A pessoa a quem se fala - A quem?

Definidos esses elementos, exprimi-se a categoria de ouvinte: espectador ou juiz; e o tempo que lhe é próprio (passado, presente e/ou futuro). Após tecer considerações acerca da argumentação da tese proposta (a utilização de provas, de testemunhos, de paixões, de exemplos, de máximas e de lugares-comuns de todos os gêneros), Aristóteles, no último livro, apresenta um estudo da forma do discurso. No terceiro livro é que ele argumenta, em um primeiro momento, acerca das virtudes dos estilos, de um modo geral, a saber: clareza; escolha da linguagem; emprego de vocábulos usuais e compostos; utilização de metáforas e conjunções; comparações; dentre outras. Posteriormente, no capítulo XII, Aristóteles explicita o estilo próprio de cada um dos gêneros, para que, no capítulo seguinte, aponte as partes do discurso em que, em sua opinião, levarão à persuasão do ouvinte e ao cumprimento do dever de um bom orador-autor: Proêmio (também encontramos como tradução os termos: Preâmbulo e Exórdio), Argumentação (Exposição ou Narração) e Epílogo (ou Peroração). A utilização que faremos do manual de Aristóteles se concentrará, mais enfaticamente, nesses últimos capítulos do terceiro livro, nos quais podemos dividir as partes do discurso, de acordo com os seus propósitos e características de argumentação. Cabe salientar que cada retor monta seu manual de acordo com as características político-culturais de sua época. Compete a nós, antiquistas da contemporaneidade, saber selecionar quais elementos retóricos são pertinentes à interpretação dos documentos do século IV d.C.

Após essas considerações acerca de algumas ideias contidas no manual de Aristóteles partiremos para a análise retórica do Apologia e do Contra Eunômio, a fim de compreender a composição do discurso, de maneira inversa. Queremos dizer, com isso, que nossa estratégia de 
interpretação é fazer o caminho inverso no qual tais discursivos foram concebidos: da construção para a desconstrução retóricas.

\section{O Embate Discursivo Retórico}

Como primeiro passo, nessa interpretação retórica, identificamos a definição dos gêneros Apologia e Contra Eunômio. ${ }^{6}$ Posteriormente, separamos as seções que compõem as diferentes partes do discurso, propostas no manual utilizado e, por último, analisamos os códigos retóricos contidos em cada uma dessas partes do discurso. A escolha dos fragmentos aqui utilizados foi pensada a partir da contenda, nos quais esses testemunhos estão inseridos, ou seja, procuramos selecionar trechos que pudessem dar mais informações sobre a controvérsia entre os nicenos e os arianos.

Para definição do gênero partiremos das perguntas propostas por Aristóteles: A pessoa que fala; $\mathrm{O}$ assunto; A pessoa a quem se fala.

Apologia:

Quem: Eunômio

Assunto explícito: Defesa pessoal

A quem: Juízes (religiosos) do Concílio de Constantinopla de 360 d.C.

Assunto implícito: Demonstração/Propaganda de sua doutrina

A quem: Contrários de sua doutrina (principalmente nicenos), novos adeptos, apoio do poder central e sua esfera administrativa.

\section{Contra Eunômio:}

Quem: Basílio

Assunto explícito: Refutação do discurso Apologia de Eunômio

A quem: Eunômio e seus discípulos e amigos nicenos

Assunto implícito: Demonstração/Propaganda de sua doutrina

A quem: Contrários de sua doutrina (arianos), novos adeptos, apoio do poder central e sua esfera administrativa.

Ressaltamos que as informações que possuímos sobre Basílio e sua obra são mais abundantes devido ao seu rico epistolário. A partir do conteúdo de uma carta de sua autoria, endereçada ao seu amigo Leôncio, o Sofista, é que pudemos determinar que Basílio também destinou o seu discurso para seus amigos, os quais comungavam de sua doutrina. Tal carta foi enviada no período em que Basílio estava elaborando o seu Contra Eunômio.

Raras são as cartas que eu te envio [...], pois são numerosas minhas ocupações e, por isso, peço desculpas pela ausência de notícias e pela linguagem vulgar com a qual me dirijo a um sofista [...] que, em todas as ocasiões, faz entender vossa voz ao público, porque vós sois o mais capaz, que já conheci, de falar aos gregos [...]. Eu vos enviei meus escritos contra Eunômio: faz-se necessário chamá-lo de uma 
mera brincadeira de criança ou qualquer coisa menos séria do que isso. Eu vos deixarei julgar por você mesmo, o seu conteúdo, mas eu espero que minhas palavras não se tornem uma arma sem valor contra os ímpios que vós encontrais [...]. Se quaisquer pontos de minha argumentação vos parecer frágeis, não hesiteis em me reprovar [...] (Carta 20. Datada em 364 ou 365 d.C. Grifo nosso).

Ao identificarmos o assunto e os destinatários dos discursos em questão, entendemos que seu estilo pertence ao gênero judiciário, pois, ao mesmo tempo em que Eunômio se defende, ele acusa os 'maldosos e caluniadores', enquanto que Basílio, ao mesmo tempo em que acusa, se defende das palavras proferidas pelo ‘ímpio’ Eunômio.

São três os gêneros da retórica, do mesmo modo que três são as categorias de ouvintes dos discursos (ARISTÓTELES, I-3,1). Uma acusação comporta a acusação e a defesa: normalmente os que pleiteiam fazem uma destas duas coisas ou as duas (ARISTÓTELES, I-3,3).

Além disso, na retórica judiciária, o ponto principal da controvérsia deve ser exposto no preâmbulo do discurso. Vide a exemplificação da defesa (assunto explícito) e acusação (assunto implícito) de Eunômio, no primeiro fragmento do texto:

Caluniar e atacar os outros é exercício de intemperados argumentos e da inconsistência do pensamento. É uma obra maldosa que vem de homens maus que não hesitam suas palavras ao acusar os que pensam de forma adversa. Não podemos aceitar as críticas caluniosas dirigidas contra nós. Temos estimada intenção que será útil a nossa própria apologia para a segurança da verdade ao confessarmos nossa própria crença (EUNÔMIO, 1, 1-20).

Exemplificação da acusação (assunto explícito) e defesa (assunto implícito) de Basílio, no primeiro fragmento do texto:

Se existem aqueles que falam em nome de Deus e invocam o nome do Salvador Jesus Cristo contra a verdade do Evangelho e dos apóstolos, faz-se necessário que nós venhamos $[\ldots]$ mostrar a verdade e refutar sua mensagem, conforme a crença que nos foi comunicada pelo Senhor (BASÍLIO, I, 1, 4-7).

Ao mesmo tempo em que constatamos que Eunômio e Basílio tiveram a intenção de embutir nos discursos seus ideais político-religiosos, por meio da propaganda doutrinária, também podemos perceber suas preocupações com a estrutura retórica ao respeitarem os gêneros dos discursos contidos nos manuais de retórica. O gênero judiciário, o qual acreditamos ser os dos discursos analisados, devem se preocupar em acusar e/ou defender alguém ou algum pensamento. Dessa forma, Eunômio e Basílio encontram argumentos para que se torne necessária à propaganda político-doutrinária: 
Será útil a nossa própria apologia para a segurança da verdade ao confessarmos nossa própria crença (EUNÔMIO I, 1).

Faz-se necessário que nós venhamos [...] ajudar a verdade e refutar sua mensagem, conforme a crença que nos foi comunicada pelo Senhor (BASÍLIO, I, 1, 6-7)

Ambos religiosos sabiam que para o sucesso da persuasão, a escolha e a fidelidade ao gênero escolhido eram fundamentais, pois "cada gênero oratório convém um estilo diferente" (ARISTÓTELES, III, 12-1).

O gênero judiciário tem a finalidade do juízo, ou seja, de ser julgado, pois não há necessidade de discursos para os pontos que já estavam legitimados. Além dessa característica da retórica judiciária, destacamos que, quando se fala contra um adversário ou se combate uma tese proposta, é necessário, segundo a Arte Retórica, citar palavras do oponente, para que o argumento possa ser combatido. É o que podemos perceber no fragmento abaixo:

Ponto a ser julgado: a questão da divindade de Jesus.

Nós cremos em um só Deus, Pai todo Poderoso, 'de onde tudo vem'; em seu Filho, Verbo criado, nosso Senhor Jesus Cristo e no Espírito Santo [...], cujas graças são repartidas de acordo com sua santidade e conforme a justa proporção Àquele único, cuja substância é divina (EUNÔMIO, 5, 1-6).

A estrutura do Contra Eunômio foi pensada por Basílio para refutar, em primeiro lugar, a obra e palavras contidas na Apologia. Dessa forma, conforme citamos na ocasião do tratamento documental da obra, Basílio cita os fragmentos da Apologia, aos quais fazia seguir suas próprias confutações. Ainda sobre o ponto a ser julgado, destacamos:

Eunômio: Nós cremos em um só Deus, Pai todo Poderoso,'de onde tudo vem' [...] (BASÍLIO, I, 4, 30-34).

Basílio: Essa informação, de que o Filho não possui a mesma substância divina do Pai, está cheia de contradições que nós devemos combater (BASÍLIO, I, 4, 38-42).

Outra característica de construções retóricas relacionadas ao gênero que o discurso possui é o tempo a que ele pertence. No caso específico da retórica judiciária é o passado, pois a acusação e/ou a defesa incorre sobre fatos do pretérito. Vide os trechos abaixo que constatam a determinação de tal gênero aos testemunhos utilizados:

As injúrias dolorosas e funestas dirigidas a nós são exercidas pelos homens maus por meio de artífices variados: por palavras ou atos [que já ocorreram] eles não hesitam em nos acusar (EUNÔMIO, 1, 11-17). 
A eles que já apresentaram suas idéias, nós podemos apresentar nossa refutação como um remédio contra o mal [...] (BASíLIO, I, 1, 20-23).

A acusação e a defesa, pertinentes ao gênero judiciário, perpassam a seguinte questão: certo ou errado em relação a que? Os resultados conciliares e sinodais foram, muitas vezes, legitimados em forma de lei pelos imperadores. Entretanto, principalmente durante o maior período em que o Contra Eunômio foi escrito (sob o governo de Juliano), encontrou-se um amplo espaço para as discussões doutrinárias. Dessa forma, entendemos que, ao exporem e professarem fés distintas da do poder central, Eunômio e Basílio encontraram espaço político-religioso para basear suas acusações, mais nas ditas Sagradas Escrituras do que nas leis do Império, a partir das quais reclamavam deter a verdade sobre a natureza do Filho.

A busca pela detenção da verdade é mais uma característica da qual o discurso cristão se apropriou da retórica clássica. Segundo Aristóteles, as artes retóricas devem convencer os ouvintes da justiça e da verdade daquilo que se argumenta:

A Retórica é útil, porque o verdadeiro e o justo são, por natureza, melhores que seus contrários. Donde se segue que, se as decisões não forem proferidas como convém, o verdadeiro e o justo serão necessariamente sacrificados: resultado este digno de censura (ARISTÓTELES, I, 1-12).

Enfim, é pelo discurso que persuadimos sempre que demonstramos a verdade ou o que parecer ser a verdade, de acordo com o que, sobre cada assunto, é suscetível de persuadir (ARISTÓTELES, I, 2-6).

Consequentemente, podemos visualizar, em ambos testemunhos, a grande recorrência às Escrituras, ao Evangelho e aos apóstolos para obter legitimidade, e dar o veredicto de verdade aos seus discursos e aos seus ideais político-religiosos:

Base da acusação e da defesa nos dois discursos: a verdade era determinada pelas Escrituras.

Mas preferimos aos ensinamentos de nosso Senhor Jesus Cristo, à toda massa de homens, à toda ambição ou rivalidade, à tudo que obscurece os critérios da alma (EUNÔMIO, 2, 8-12).

Paulo, o apóstolo, nos explicou: 'Deus é a primeira de todas as coisas e, a partir Dele, todas as coisas foram criadas [...] (EUNÔMIO, 24, 5-11).

Eunômio faz sua demonstração do vocábulo 'criatura', a partir de uma compreensão diferente e de uso vulgar àquela emprega nas Escrituras (BASÍLIO, II, 8, 42-47).

Ele [Eunômio], sem dúvida, compreende muito bem os pontos que separam o cristianismo do erro dos helenos e dos judeus, mas, de minha parte, acredito que não existe doutrina mais importante do que a do Evangelho (BASÍLIO, II, 22, 1519). 
Após a constatação do gênero dos discursos e de suas formas estilísticas, versaremos acerca da organização retórica dos testemunhos. Conforme citamos anteriormente, a estrutura retórica de um texto compreende-se em três partes: Proêmio, Argumentação e Epílogo; sob as quais Aristóteles separa em duas partes:

O discurso comporta duas partes, pois é necessariamente importante indicar o assunto de que se trata e, em seguida, fazer a demonstração. Pelo que, uma vez indicado o assunto, é impossível não fazer a demonstração como o é, não fazer esta demonstração sem previamente ter anunciado o assunto; com efeito, quando se demonstra, demonstra-se alguma coisa e só se anuncia uma coisa a fim de demonstrar (ARISTÓTELES, II -13).

A partir do exposto, identificamos:

Apologia (28 Seções - 33 páginas)

a) Primeira parte (Seções de 1 a 4 - 4 páginas). Eunômio indica o assunto que vai abordar: defesa das calúnias sofridas, sem dizer quais foram:

Diante dos falatórios e das maledicências ao nosso respeito, consideramos que nossa apologia será útil à segurança de nossos pensamentos, por isso, exponho por escrito a confissão de nossa própria crença (EUNÔMIO, 1, 18-20).

b) Segunda parte (Seções de 5 a 28 - 29 páginas). Eunômio demonstra por que considera como calúnias as palavras que lhe foram dirigidas:

[...] aqueles que são responsáveis por essas ímpias acusações não aperfeiçoam seus pensamentos e não estão no direito de fazer acusações audaciosas contra nós. Ao que nos cabe, temos exposto durante santos períodos e, agora, novamente expomos: a substância de Deus não admite uma divisão, pois ela, em si mesma, não foi gerada; ela igualmente não permite uma separação ou uma divisão, pois a substância de Deus é indivisível (EUNÔMIO, 15, 1-8).

Contra Eunômio (Livro I: 27 Seções, Livro II: 34 Seções e Livro III: 7 Seções - 148 páginas)

a) Primeira parte (Livro I: Seção 1 - 4 páginas). Basílio indica o assunto que vai abordar: acusa Eunômio como inimigo da verdade e propõe a sua refutação:

Mas veja que o inimigo da verdade faz renascer o mal e, com os instrumentos de sua técnica, ele propõe a negação da divindade de Jesus sob a aparência de um cristianismo (BASÍLIO, I, 1, 7-11).

Eunômio tem a ambição de se autoproclamar autor e chefe de um grupo inteiro de heréticos: tal personagem é quem nos propomos a contestar (BASÍLIO, I, 1, 4041). 
b) Segunda parte (Livro I Seções de 2 a 27, Livro II, Livro III - 144 páginas). Basílio argumenta por que sua refutação é necessária:

Como ponto de partida para minha refutação, darei atenção a partir de agora, ao próprio título de seu discurso: Apologia. A primeira de todas as suas más ações, que chegou ao meu conhecimento, foi à forma que ele deu à sua argumentação: resumiu seus pensamentos sob o nome de uma defesa (BASÍLIO, I, 2, 1-4).

Sobre a organização retórica e partes do discurso, é no Proêmio que o orador mostra o objeto de seu discurso e expõe o ponto a ser julgado utilizando as regras de confiabilidade, ou seja, tenta conquistar a benevolência do seu ouvinte por meio do recurso retórico chamado Captatio Benevolentiae.

A Captatio Benevolentiae é uma figura retórica em que o orador tenta assegurar-se da simpatia do receptor, servindo-se de expressões aduladoras com a intenção de atrair a atenção e simpatia do ouvinte; e, posteriormente, do leitor. Após a conquista da benevolência, faz uso de expressões imperativas e perguntas que levam o receptor a respostas imediatas que favoreçam sua causa defendida. Com esse recurso, o orador pretende receber louvor e solidariedade para a causa que está a ser defendida.

Em seguida, na Argumentação, o orador mostra suas provas por meio dos exemplos e das máximas. Essa parte é considerada o cerne da persuasão, onde o autor argumenta acerca de sua acusação e/ou defesa.

O Epílogo é a parte em que o orador finaliza e conclui o seu discurso. É formado de quatro segmentos, nos quais, em um primeiro momento, o objetivo é a aproximação do ouvinte por meio da Captatio Benevolentiae, em detrimento de uma imagem desfavorável do oponente. Em seguida, as máximas são recapituladas em seus extremos (certo e errado; justo e injusto; verdade e calúnia). O terceiro segmento do epílogo é reservado ao apelo passional no ouvinte e, por último, o orador deve recapitular suas conclusões.

Diante do exposto, constatamos as seguintes seções:

\section{Apologia}
a) Proêmio: Seção 1 a 6.
b) Argumentação: Seção 7 a 25 .
c) Epílogo: Seção 26 a 28.

\section{Contra Eunômio}

a) Proêmio: Livro I - Seção 1 a 3.

b) Argumentação: Livro I - Seção 4 a 22, Livro II, Livro III - Seção 1 a 6.

c) Epílogo: Livro I - Seção 23 a 27, Livro III - Seção $7^{7}$. 
No intuito de exemplificar, por meio de fragmentos dos discursos, a contenda entre o ortodoxismo cristão niceno e o heterodoxismo cristão ariano, selecionamos temas que nos auxiliaram a expor o conflito:

Demonstração do uso da Captatio Benevolentiae no Proêmio dos discursos.

Exemplo do uso do imperativo:

Não procurem diferenciar a mensagem da verdade,de acordo com o número vantajoso daqueles que dizem ser correto e justo o que falam. Não os deixem obscurecer vosso pensamento por causa da bazófia de alguns. Não deem vantagem ao partido que tomou a frente para tapar-vos os ouvidos. Somente peço que julguem os fatos que vos trago com benevolência e verdade (EUNÔMIO, 2, 5-10).

Exemplo do uso de apelo passional ao público:

Criou-se então uma necessidade, para nós, de mostrar a verdade, tanto devido à nossa caridade, que nos fazia uma ordem, como também a nossa própria segurança, embora não fôssemos atraídos por este tipo de tratado (BASÍLIO, I, 2, 15-17).

Defesa do ponto julgado: argumentação acerca da questão cristológica:

Necessitariam, com efeito, se eles tem alguma preocupação com a verdade, confessar que se os nomes [Pai e Filho] são diferentes, as substâncias também o são (EUNÔMIO, 18,15-18).

Por exemplo: homem, cavalo, boi, exprimem o nome das coisas; mas filho, escravo ou amigo indicam somente a ligação que existe entre os termos. Por isso, a palavra criatura não deve ser incluída na discussão sobre a substância, pois ela está relacionada à ligação com outro termo, não com a natureza deste termo (BASÍLIO, II, 9, 17-21).

Argumentação de Basilio contra o discurso do oponente com o propósito de tirar-lhe a credibilidade. É nesse momento que identificamos as provas que o autor apresenta para persuadir e converter o ouvinte/leitor à sua causa.

E como o mal é único nesses dois homens [Aécio e Eunômio], fica claro que através do discípulo podemos conhecer o mestre. Este também será julgado pelo erro de seu discípulo, pois foi dele que saíram as sementes da impiedade (BASÍLIO, I, 1, 41-44).

Sob o pretexto de uma apologia, ele capta a benevolência de seu público levandoos a crerem em suas calúnias, pois estas são amenizadas quando expostas sob este artifício (BASÍLIO, I, 2, 1-4). 
Juizo de valor: uso de adjetivos e termos para denegrir o oponente.

Não os deixem obscurecer vosso pensamento por causa da bazófia de alguns. Não deem vantagem ao partido que tomou a frente para tapar-vos os ouvidos (EUNÔMIO, 2, 7-9).

Eu possuo inúmeras maneiras de mostrar que seu tratado é mentiroso, ignorante, orgulhoso, dissimulado, blasfemador; contudo, o farei de uma maneira digna da glória de Deus. Mostrarei suas técnicas para mascarar seus reais objetivos (BASÍLIO, I, 1, 48-53).

Ele queria, de qualquer maneira, difundir seu discurso perverso e ateu, e conquistar um público para atrair adeptos a sua blasfêmia (BASÍLIO, I, 2, 7-9).

O termo criatura é resultado de um delírio e de um falatório (BASÍLIO, I, 6, 3-4).

Preocupação com a unidade do cristianismo: Eunômio e Basilio não falam em nome de si mesmos, mas em nome do cristianismo.

Os discursos Apologia e Contra Eunômio apresentam preocupações acerca da unidade do cristianismo que nós entendemos também como uma preocupação com a unidade do Império. Cada ideal político-religioso está inserido na afirmação do discurso cristão que ocorreu durante todo o século IV d.C.

A profissão de fé, verdadeira e simples como ela é, deve ser comum a todos aqueles que se dizem cristãos [...]. Nós podemos ver que se todos utilizassem e aceitassem os mesmos inteligentes e verdadeiros termos, poderíamos por um ponto final no nosso próprio discurso, pois nossa confissão de fé, se aceita por todos, nos garantiria tranquilidade [enquanto cristãos] (EUNÔMIO, 6,1-12).

Como uma grande conspiração, alguns dão suas mensagens separadas da verdade e, em nome da segurança, da glória e do interesse público solicitamos que, pelo menos, os que seguem nossos ensinamentos, guardem de forma firme e sólida sua fé a partir do que defendemos até o julgamento do Nosso Senhor (EUNÔMIO, 27, 34-41).

Ele [Eunômio] não se encontra no interior da nossa Igreja [não era defensor da ortodoxia nicena], entretanto, não é como um estrangeiro diante a nossa doutrina [era cristão] e, mesmo assim, como uma paralisia mental, elabora seus pensamentos contra a verdade sobre a geração do Filho [ou seja, é cristão, o que correto na visão de Basílio. Porém, sua mente paralisa ao refletir sobre a natureza do Filho] (BASÍLIO, I, 5, 36-41)

Exemplo da preocupação de Eunômio com as várias interpretações do cristianismo e do papel dos concílios eclesiásticos nessa contenda.

Mas não é suficiente admitir a verdade, é preciso lutar por ela. Pois a maldade e a perversidade de julgamento sempre existirão para deformar e 
corromper o sentido único, mas nem Sabélio, nem Marcelo de Ancira ${ }^{9}$, nem Plotino, ou quaisquer outros que defendem as mesmas loucuras que eles, serão capazes de nos calar ou impedir que expliquemos nossos pensamentos. Se não fosse loucura o que dizem, eles não teriam sido excluídos da comunhão e dos mistérios nas assembléias eclesiásticas (EUNÔMIO, 6,1-12).

Exemplo da preocupação de Basílio com as várias interpretações do cristianismo contida em sua carta de número 210 destinada aos Cidadãos da Cidade de Neocesaréia e a Carta 244 enviado ao seu amigo Bispo Patrófilo:

Escrevo-vos para informar de assuntos que devemos combater com nosso sangue. É chorando sobre a minha alma que fui obrigado a lutar contra dois adversários que querem afastar a verdade e colocar em risco a nossa doutrina. De um lado estão os anomeanos, que nos denigrem; e de outro estão os sabelianistas. Mas eu vos peço que tomem cuidado com os seus sofismos infames com os quais apelam para a superioridade do Pai sobre o Filho [...] (Carta 210. Datada em 375 d.C.).

Os barulhos que circulam agora, mostram que a lei de Niceia foi contaminada: os barulhos que vem de Cízico propõe outra fé (Carta 244, 5. Datada em 376 d.C.).

Exemplo da acusação de Basílio contra Eunômio ao utilizar o espaço político-religioso de concílios como propaganda pessoal. Nesse fragmento, conseguimos detectar exemplos dos dois planos nos quais visualizamos a contenda, ou seja, as disputas episcopais nas reuniões eclesiásticas com interferência do poder central e a questão da divisão territorial do Império Romano. Esta última encontrava-se aliada à distribuição das sedes episcopais. Caracterizamos assim, mais uma vez, o teor político-religioso do conflito:

Entretanto, qual a sua razão em guardar silêncio até esse momento e, agora, nós os interrogamos: Quem são os acusadores que lhe dirigiram as calúnias e são contrários a sua apologia? De qual parte do Império eles pertencem? Quem são os juízes que ele quer combater? Onde eles estavam reunidos? Em Selêucia ${ }^{\mathbf{1 0}}$ ? Mas eles não foram condenados ao silêncio, pois os membros daquela assembléia obtiveram o veredicto ao seu favor [...]. Eles deveriam ser arrancados da Igreja [pelos concílios] assim como fazemos com a doença para que o corpo fique saudável [...]. Em Constantinopla ${ }^{11}$ ? Mas lá também não houve necessidade de um discurso de defesa, pois já obtinham ao seu lado as pessoas da corte imperial e outros personagens influentes. Apoiados nesse público é que nos atacaram com uma posição de superioridade. Eles mesmos eram os juízes que determinaram nossas suspensões e deposições. Com esses plenos poderes, podiam compartilhar as cidades, como o que ocorreu com as da Síria, Constantinopla e Cízico $^{12}$, as quais pagarão os preços por toda essa impiedade (BASÍLIO, I, 2, 5075). 
Exemplo da consciência e propaganda do ideal político-religioso de Eunômio:

A religião [no sentido do cristianismo como um todo], que defendemos agora [que segue os seus ensinamentos sobre a natureza do Filho], se beneficiará do nosso combate, pois a verdade julgará a todos: ao mesmo tempo que liberta os bons, a verdade despreza os perversos e lhes darão castigos inevitáveis. Há duas saídas para escolher: a liberdade e o desprezo (EUNÔMIO, 27, 45-50).

Demonstração de elementos conclusivos no Epílogo

Nos restam duas saídas para escolher: a liberdade e o desprezo. E que no fim [fim do seu discurso e no julgamento final], ganhe o melhor partido! (EUNÔMIO, 27, 51-52).

Nosso discurso também pode ser visto como uma profecia, cujas palavras vieram diretamente do Senhor. Sua voz vinda do céu pode nos lembrar os golpes de trovões que Deus Pai emitiu para anunciar seu Filho aos homens [...] (BASÍLIO, III, 7, 24-28).

Exemplo do uso da Captatio Benevolentiae no Epílogo por Eunômio, a fim de finalizar seu discurso obtendo a afeição do público. Durante essa parte do discurso, Eunômio faz alusões repetidas a sua audiência e dialoga com os seus ouvintes, aos quais agradece pela paciência, além de fazer um apelo passional aos juízes ao pedir um julgamento justo:

A fim de evitar que a demora do nosso longo discurso não desanime nosso auditório, concentraremos brevemente todas as nossas forças para recapitular o que afirmamos anteriormente: que Deus é universal e único verdadeiramente divino, não gerado, sem início, incomparável, superior [...] (EUNÔMIO, 26,1-8).

\section{Considerações Finais}

A escolha das temáticas, bem como a seleção dos fragmentos, teve o intuito de melhor expor nossa compreensão da contenda a partir dos dois planos: relação entre poder imperial - poder episcopal e relação entre unidade territorial - unidade político-religiosa.

Por meio desses temas intentamos ilustrar vários aspectos que fizeram parte dessa contenda cristã, tais como: questão cristológica; propaganda nos concílios e circulação de ideais cristãos político-religiosos; intervenção do poder central nas questões político-religiosas; tentativas de afirmação do discurso cristão; busca pela verdade/ortodoxia; uso dos manuais de retórica; uso de formas estilísticas e utilização da mesma estrutura retórica.

No que diz respeito à utilização da estrutura retórica presente na argumentação do Apologia e Contra Eunômio, procuramos contrastar os trechos dos testemunhos a fim de caracterizar o embate discursivo e apresentar as formas estilísticas utilizadas por ambos. Enfim, com a mesma estrutura 
retórica, mas com diferentes formas de pensar sobre a unidade imperial romana, Basílio e Eunômio defenderam a sua verdade.

Com a visualização da contenda, através dos fragmentos dos discursos expostos nesse artigo, podemos concluir a respeito da pluralidade de fatores nos quais esse conflito estava envolto:

A questão cristológica configurou-se na problemática direta, enquanto que a propaganda do ideal político-religioso nos concílios, em busca do apoio imperial, tornou-se o pano de fundo dessa contenda;

A disputa hierárquica dos dois bispos representava as várias tentativas de afirmação do discurso cristão. $\mathrm{O}$ embate discursivo almejava um fim comum às várias propostas doutrinárias existentes naquela época: a busca pela verdade sob o título de ortodoxia;

A busca pela unidade do cristianismo criou um espaço propício para a unidade ideológica de cada grupo cristão. Tal unidade possuía pontos híbridos que congregava e/ou contrastava os grupos religiosos do período;

A disputa hierárquica foi uma forma simbólica de busca por uma autoridade que proporcionasse legitimidade a determinadas instâncias de decisões religiosas, como os sínodos e concílios.

Percebemos então, que essas determinações e regras concernentes, a uma primeira vista, aos aspectos e elementos relacionados à religião, sempre estiveram ligadas ao engaste entre política e religião no Império Romano do século IV d.C., já que o discurso considerado vencedor foi aquele que obteve apoio do Imperador, legitimado e legalizado pelo governante em cada momento histórico do Império.

\section{Referências Bibliográficas}

Documentação Impressa

ARISTÓTELES. Arte Retórica. Tradução de Antônio Pinto de Carvalho. Introdução e notas de Jean Voilquin e Jean Capelle. Rio de Janeiro: Ediouro, 199-.

ARISTOTELES. The Art of Rhetoric. Transl. em inglês por John Henry Freese. Cambridge: Cambridge University Press, 1991.

BASILE de Cesarée. Contre Eunome. Introduction, Traduction et notes de Bernard Sesboüé. Tome I, n²99; Tome II, nº 305. Paris: Cerf, 1982-1983.

BASILE de Cesarée. Lettres. Texte établi et traduit par Yves Courtonne. Paris: Les Belles Lettres, 1957-1966, 3v.

EUNOME de Cyzique. Apologie. Introduction, Traduction et notes de Bernard Sesboüé. Tome II, $\mathrm{n}^{\mathbf{0}}$ 305. Paris: Cerf, 1983. 
Obras Gerais

ALEXANDRE JUNIOR, Manuel. Hermêutica retórica. Um código integrado de interpretação. EVPHROSYNE, Revista de Filosofia Clássica, Faculdade de Letras de Lisboa, v. 31, p. 99-114, 2003.

BRANDÃO, Helena H. Nagamine. Introdução à análise do discurso. 2. ed. rev. Campinas: Editora da UNICAMP, 2004.

CAMERON, Averil. Chtistianity and the Rhetoric of Empire. The development of Christian Discourse. Berkely, Los Angeles, London: University of Califórnia Press, 1994.

CAPE JUNIOR, Robert W. Persuasive history: Roman rhetoric and historiography. In: DOMINIK, William J. Roman Eloquence. London/ New York: Routledge, 1997, p.212-228.

CARRIÉ, J.-M; ROUSSELLE, A. L'Empire Romain en mutation, des Sévères à Constantin. Paris: Éditions du Seuil, 1999.

CARVAlHO, Margarida Maria de. Paidéia e Retórica no Século IV d.C.: A Construção da Imagem do Imperador Juliano Segundo Gregório Nazianzeno. 2002. Tese (Doutorado em História) Faculdade de Filosofia, Letras e Ciências Humanas, Universidade de São Paulo, São Paulo, 2002.

CHIAPPETTA, Angélica. Retórica e Crítica literária na Antigüidade. PHAOS, Revista de Estudos Clássicos, Campinas, SP, v.1, p. 39-60, 2001.

DROBNER, Hubertus R. Manual de Patrologia. Petrópolis, RJ: Vozes, 2003.

FUNARI, Pedro Paulo A. As formas o discurso historiográfico. In: VERNANT, Jean-Pierre; FUNARI, Pedro Paulo A.; HINGLEY, Richard. Textos Didáticos: Repensando o Mundo Antigo. 2. ed. rev. e aum. Campinas: IFCH/UNICAMP, 2005, p.63-70.

GAIN, Benoît. L'Église de Cappadoce au IVe. Siècle d'aprés la correspondance de Basile de Césarée, 330-379. Rome: Orientalia Christiana Analecta, 1985.

GALVÃO-SOBRINHO, Carlos R. Embodied Theologies: Christian Identity and Violence in Alexandria in the Early Arian Controversy. In: DRAKE, H. A. (ed.) Violence in Late Antiquity. Perceptions and Practives, Ashgate, Aldershot, 2006, p.321-331.

GANGLOFF, Anne. Mythes, fables et rhétorique à l'époque imperiale. Journal of the History of Rhetoric, University Califórnia Press, v.20, n.1, p.25-56, 2002.

GIET, Stanislas. Saint Basile et le Concile de Constantinople de 360. The Journal of Theological Studies, Oxford, n.VI, p.94-99, 1955.

HAMMAN, Abalbert G. Os padres da Igreja. 3ª ed. São Paulo: Paulinas, 1983.

HANSON, R. P. C. The search for the Christian Doctrine of god. The arian Controversy 318-381. Scotland: T\&T Clark, 1997.

JENKINS, Keith. A História Repensada. São Paulo: Contexto, 2005. 
MAGALHÃES, Júlio César. Arianistas. In: FUNARI, P.P.A. (org.). As Religiões que o Mundo esqueceu. Como egípcios, gregos, celtas, astecas e outros povos cultuavam seus deuses. São Paulo: Contexto, 2009, p.87-101.

MORESCHINI, Cláudio; NORELLI, Enrico (orgs.). História da Literatura Cristã Antiga Grega e Latina. São Paulo: Loyola, 2000.

PERNOT, Laurent. The Rhetoric of Religion. Journal of the History of Rhetoric, University Califórnia Press, v.24, n. 3, p. 235-254, 2006.

SILVA, Gilvan Ventura da. Reis, Santos e Feiticeiros: Constâncio II e os fundamentos místicos da basiléia. (337-361). Vitória: Edufes, 2003.

SPINELLI, Miguel. Helenização e Recriação de Sentidos. A Filosofia na Época da Expansão do Cristianismo - Séculos II, III e IV. Porto Alegre: EDIPUCRS, 2002.

WICKHAM, L. R. The date os Eunomius 'Apology: a reconsideration. The Journal of Theological studies, Oxford, n.XX, p.231-240, 1969.

\section{NOTAS}

${ }^{1}$ Este artigo é baseado em nossa Dissertação de Mestrado intitulada Cristianismo Ortodoxo versus Cristianismo Heterodoxo: Uma Análise Político-Religiosa da contenda entre Basilio de Cesaréia e Eunômio de Cízico (Séc. IV d.C.) sob a orientação da Profa. Dra. Margarida Maria de Carvalho com financiamento da FAPESP.

${ }^{2} \mathrm{O}$ termo niceno provém de Nicéia, importante cidade localizada no Império Romano Oriental, próxima a capital Constantinopla. Tal cidade sediou o Concílio de Nicéia em 325 d.C., presidido pelo Imperador Constatino. Sendo assim, cristãos nicenos são os religiosos que aceitam e advogam a causa do que foi decidido no Concilio de Nicéia, ou seja, acreditam na consubstancialidade entre Pai e Filho.

${ }^{3}$ Os arianos, assim denominados os discípulos de Ário, defendiam que a substância de Jesus era semelhante (e não a mesma) da de seu Pai, ou seja, apoiavam essa vertente cristã ao invés da nicena. Ressaltamos que nenhuma proposta de fé (ou verdade) pretendeu ser alheia à fé cristã. Almejava-se uma fé única e verdadeira.

${ }^{4}$ Lembramos que o Apologia foi declamado e posteriormente escrito, conforme fragmentos do próprio Eunômio:

"Diante de tudo, nós vos pedimos, a vós que vais nos escutar agora e a vós que nos lereis mais tarde, não procureis diferenciar a mensagem da verdade de acordo com o número vantajoso, daqueles que dizem ser correto e justo o que falam" (EUNÔMIO, 2, 1-5).

Sobre Contra Eunômio, apesar de não termos evidências de fragmentos diretos, acredita-se (WICKHAM, 1969, p.235; SPINELLI, 2002, p.248;) que tal discurso também tenha sido proclamado antes de escrito.

${ }^{5}$ Citamos esses dois escritores, pois ambos foram renomados mestres retóricos e amplamente utilizados no século IV d.C. Em nossa dissertação de mestrado, além do manual de Aristóteles, também utilizamos Sobre as Formas de Estilo de Hermógenes de Tarso.

${ }^{6}$ Os discursos serão citados nessa ordem, durante toda nossa análise, pois Contra Eunômio é uma refutação do Apologia e, portanto, escrito posteriormente.

7 Informamos que encontramos características de Epílogo, no final do Livro I e no Livro III. Ressaltamos que os fragmentos do discurso de Basílio referentes a essa temática são em menor número quando comparados ao discurso de Eunômio, pois, conforme Sesboüé (Trad. BASILE DE CÉSARÉE, 1983, p.174-175) nos esclarece, o final do Contra Eunômio é interrompido de forma abrupta e sem muitos elementos conclusivos. Sesboüe acredita que tal fato ocorra porque Basílio continua o assunto do Livro III em outro discurso específico, intitulado Tratado sobre o Espírito Santo. A essa explicação acrescentamos e supomos que os últimos fragmentos do Livro III não foram preservados, dado o tamanho reduzido de seções (sete).

${ }^{8}$ Tradução feita a partir do proposto por Spinelli (2002, p.286).

${ }^{9}$ O tradutor do discurso Apologia, Sesboüé (Trad. EUNOME DE CYZIQUE, 1983, p.243-244), nos informa que Marcelo foi Bispo de Ancira, ardente defensor de Nicéia que foi deposto em 355 d.C. como suspeito de ser adepto aos preceitos do sabelianismo. Já Plotino foi diácono e discípulo de Marcelo de Ancira e depois Bispo de Sírmio, e seguia os pensamentos de seu mentor. Sesboüé acredita que Eunômio cita esses três nomes, pois, assim como os nicenos, os sabelianistas acreditavam na divindade do Filho. 
${ }^{10}$ Basílio se refere ao Concílio de Selêucia (359-360 d.C.), no qual os arianos saíram vitoriosos.

${ }^{11}$ Nesse momento, Basílio se refere ao Concílio de Constantinopla de 360 d.C.

${ }^{12}$ Basílio se refere ao fato de que Eunômio foi empossado da sede episcopal de Cízico no Concílio de Constantinopla de 360 d.C.

Artigo recebido em 04/2010. Aprovado em 05/2010. 